\title{
Клинични случаи на ринофима в ринологичната практика
}

\author{
Д. Марковски, Д. Вичева \\ Катедра по оториноларингология, \\ Медицински университет - Пловдив
}

\section{Резюме:}

Розацеята е общо, но често пренебрегвано състояние на кожата, което се изявява с хронични кожни реакции на свръхчувствителност и може да доведе до значителна лицева деформация, очни усложнения, както и тежък емоционален стрес. Тя е хронична дерматоза, която се характеризира с различна степен на зачервяване, еритема, телеангиектазия, оток, папули, пустули, очни лезии, както и ринофима.

Ринофимата представлява малформация на носа с неизвестна етиология.

Най-широко приета теория е, че то е крайният етап на хронично акне розацеа и е доброкачествено, бавно, постепенно, кожно, дисфигуративно нарушение на върха на носа и се състои от нередовно удебеляване на кожата и нодуларна хипертрофична хиперемия на съединителната тькан и себацеозните жлези.

Съществуват четири варианта на ринофима (жлезна, фиброзна, фиброангиоматозна и актинозна), които могат да бъдат признати за клинична и хистологична основа. Развитието на рак на кожата, както базално-клетъчен карцином или сквамозно клетъчния карцином в ринофимата изглежда е въпрос на случайно съвпадение на различни болести.

Значителна част от пациентите са възрастни хора с хронични здравословни проблеми.

\section{Въведение}

Носът е важна част от лицето. Според неговия изглед често можем да определим характера на индивида и неговата индивидуалност.

Pинофимата е термин, получен от гръцки „rhis“ - нос и „рhута“ - растеж. Това било известно при гръцки и арабски лекари още през 2000 пр. н.е. В тези ранни дни имало няколко болести на носа, като туберкулоза, сифилис и лепра, които са били бъркани с ринофима. Тя е болест, която обикновено засяга бели мъже между 40- и 60-годишна възраст, далеч по-често при мъже, отколкото при жени, с отношение 12:1, обикновено докладвани. Много интересен факт е считането, че болестта е крайната фаза на акне розацеа, което пак е три пъти по-често при жените.

Предшественик на ринофимата е Вирхов (Virchow), който през 1846 г. я свързва с розацеа. Той констатира че освен носа заболяването включва клепачите „blepharophyma“, ухото „otophyma“, както и брадичката, „mentophyma“, но тези области са много по-рядко засегнати.

Етиологията и патогенезата на розацеята все още са неизвестни. Много от възможните причини са описани като предпоставки на заболяването: генетична предразположеност, необичайна съдова реактивност, Helicobacter pylori инфекция, Demodex folliculorum заразяване, себорея, хипертония, сенилни фактори. Въпреки това нито един от тези фактори не е доказан. 
Отключващи причини са различни екзогенни фактори (продължително излагане на сльнце, стрес, студено време, консумацията на алкохол, кафе или определени храни) и ендогенни фактори (храносмилателни смущения, гастрит, колит холецистопатия, ендокринопатия). Първа линия на лечение е избягването на тези взаимодействия или изострящи фактори.

\section{Клинична картина}

Водещия симптом е деформацията, зачервяването на външния нос и дискомфортът на пациентите. Кожата на носа е задебелена, изпъстрена с телеангиектазии, с дълбоко и силно разширени пори, наподобяващи кора на портокал. Симптомите се обикновено интермитентни, но прогресират като постоянно зачервяване на кожата на носа, мальк брой от пациентите се оплакват от сухота в очите и оток на лицето. Понякога може да доведе до обструкция на носното дишане или намаление на зрителното поле. Ендоназално не се наблюдават патологични отклонения.

\section{Диагноза}

Хистопатологично - периваскуларни смесени инфилтрати с едем в горната дерма и дилатирани съдове, хиперплазия на мастните жлези и съединителна тъкан. Търсене на Demodex folliculorum (върху кожата се залепва скоч, който веднага се отлепва и се прави миксроскопски оглед).

\section{Клинични случаи}

Представяме два клинични случая в Катедрата по оториноларингология, Медицински университет - Пловдив, като единият беше опериран по повод ринофима (Фиг. 1 и Фиг. 2), а другият пациент паралелно с ринофимата имаше локализация на ларинго-хипофарингеален карцином с превес на оплакванията от другите заболявания (Фиг. 3).

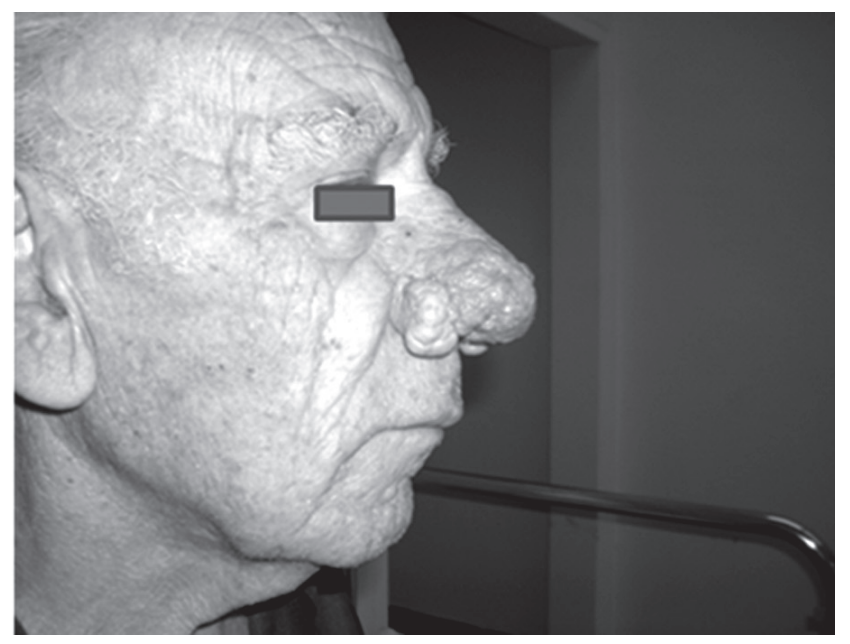

Фиг. 1. Пациент преди оперативно лечение на ринофима

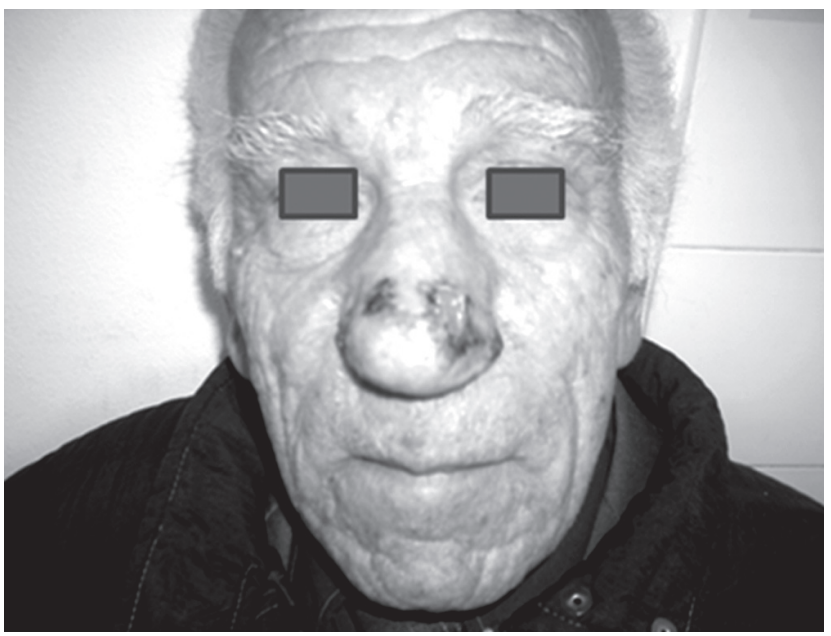

Фиг. 2. Пациент след оперативно лечение на ринофима 

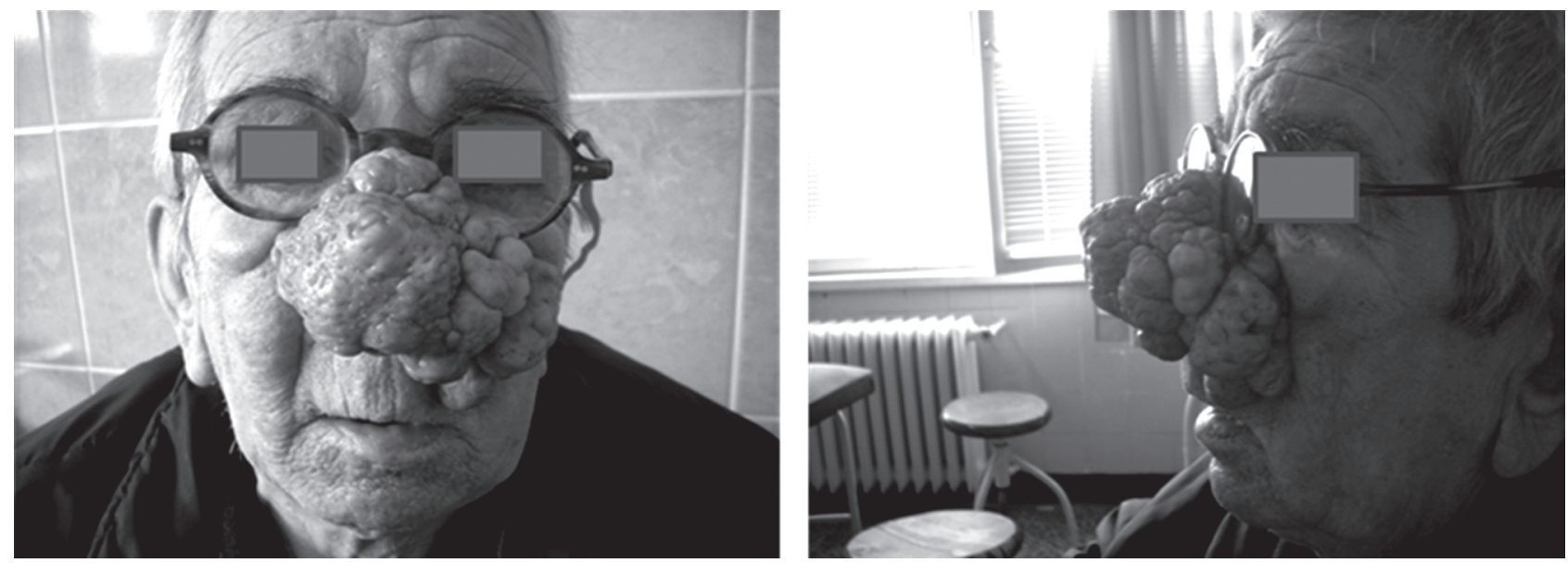

Фиг. 3. Пациент, който не беше опериран за ринофима, поради диагностициране на ларинго-хипофарингеален карцином

\section{Лечение}

Розацеята изисква дългосрочно лечение с локални или орални медикаменти, а хирургичното отстраняване е избор на лечение за ринофима и телеангиектазия (2).

Основната причина и индикация за ексцизия е козметичният деформитет, който причинява функционални проблеми, в напреднали случаи се наблюдава обструкция на носното дишане или намаляване на зрителното поле. Необходимо е проследяване на ефекта от консервативната терапия във времето, когато не е дала задоволителни клинични резултати.

Съществуват множество подходи за избор на хирургично лечение като: електрокаутер, отопляем скалпел, $\mathrm{CO}_{2}$ лазер (1), аргон лазеp, Weck ножчета, алуминиево-гранат (YAG) / $\mathrm{CO}_{2}$-лазер, дермоабразио, криотерапия, лъчелечение, пълна дебелинна ексцизия, кожни присадки, ножицареконструкция и студен скалпел (нож) (11).

Поради изключителната васкуларизация на носа по време на операцията може да се получат интраоперативни кръвоизливи. Повечето автори препоръчват частично дебелинна ексцизия като лечение от първи избор, или още наречена „декортикация.“ Идеята е ринофиматозната тъкан да се отстрани грижливо, без да се нараняват основните хрущяли. Операторът може да постави пръста в ноздрата или да използва микроскоп с цел да се спре отстраняването на тъкан с по-голяма дебелина, както се очаква да е от 2 до 3 мм над горната и долната странични носни кости, хрущялът да остане незасегнат $(3,4,5)$. На този етап останалите фунди на хипертрофични себазеозни жлези трябва да бъдат напълно достатъчни, за реепителизиране на носа.

Декортикацията запазва общата архитектура на носа и реформиране на себацеозните жлези и освен това съответства на по-близко реепителизиране до нормалното, отколкото която и да е от техниките за присаждане на кожата. Области, които са трудни за отстранение със скалпел, може да се обработят с „дермоабразия“.

Дермоабразията си остава един ефективен и надежден метод в лечението за акне белези, травматични белези на лицето и ринофима (6, 7). Тя е евтин, поносим и широко достьпен метод, който не изисква специализирано оборудване. Някои автори описват опита си с „тройния подход“" състоящ се от допирна ексцизия за събиране, използването на ножици за оформяне, както и използването на лека дермоабразия за окончателно изглаждане на контурите на носа.

Ранните усложнения включват крьвоизлив и ранна инфекция. Експонирането на носните хрущяли може да доведе до хронична инфекция и хондронекроза с външни носни деформации.

\section{Заключение}

Въпреки краткия ни практичен опит със случаи на ринофима, смеем да твърдим, че комбинацията със студен нож (ексцизия) и дермоабразия е доста успешен метод, който се практикува и в Катедрата по оториноларингология, Медицински университет - Пловдив. От направената от нас литературна справка се установи, че в момента няма научни доказателства за превъзходството на много популярната лазер хирургия $(9,10)$ в сравнение с конвенционалната студена нож хирургия, съчетана с дермоабразия за ринофима. 


\section{Литература:}

1. Ali MK, Callari RH, Mobley DL. Resection of rhinophyma with CO2 laser. Laryngoscope 1989, 99: 453-455

2. Amedee RG, Routman MH. Methods and complications of rhinophyma excision. Laryngoscope 1987; 97: 1316-1318

3. Clark DP, Hanke CW. Electrosurgical treatment of rhinophyma. J Am Akkad Dermatol 1990; 22: 831-83

4. Dotz W, Berliner N. Rhinophyma: Master image, a patron of the affliction. Am J Dermatopathol 1984; 6: 231-23

5. Eisen RF, Katz AE, Bohigian RC, Grande DJ. Surgical treatment of rhinophyma with the Shaw scalpel. Arch Dermatol 1986; 122: 307-30

6. Elliott RA Jr, Ruf LE, Hoehn JG. Rhinophyma and its treatment. Clin Plast Surg 1980; 7: 277-20

7. Farrior RT. Dermabrasion in facial surgery. Laryngoscope 1985; 95: 534-55

8. Gursel B, Yalciner D. Rhinophyma: treatment with excision and silver-impregnated amniotic membrane. Rhinology 1988; 26: 63-6

9. Haas A, Wheeland RG. Treatment of massive rhinophyma with carbon dioxide laser. J Dermatol Surg Oncol 1990; 16: 645-64

10. Hassard AD. Carbon dioxide laser treatment of acne rosacea and rhinophyma: how to do this. J Otolaryngol 1988; 17: 336-33 Lloyd km. Surgical removal of rhinophyma. Arch Dermatol 1990; 126: 721-72

11. Riefkohl R, Georgiade GS, Barwick WJ, Georgiade of. Rhinophyma: a thirty-five years experience. Aesthetic Plast Surg 1983; 7: 131-13 RK Roenigk. CO-2 laser vaporization for treatment of rhinophyma. Mayo Clin process 1987, 62: 676-60 